\title{
Supercritical carbon dioxide extraction of Vitis Vinifera Malbec seeds oil: Kinetic modelling and solubility evaluation
}

\author{
Henry Obregón, $\mathrm{Mg}^{1}$, Fredy Huayta, $\mathrm{Msc}^{1}$, Fiorella Cárdenas, $\mathrm{PhD}^{1}$, Roberto Chuquilin, $\mathrm{Mg}^{2}$, \\ ${ }^{1}$ Pontifical Catholic University of Peru (PUCP), Department of Engineering, Section of Industrial Engineering, Lima, Peru. \\ ${ }^{2}$ National University of Huancavelica, Professional Academic School of Agroindustrial Engineering, Huancavelica, Peru. \\ hobregon@pucp.pe, fhuayta@ pucp.edu.pe, fcardenas@pucp.pe, roberto.chuquilin@unh.edu.pe
}

\begin{abstract}
Experimental and modeling investigations of supercritical fluid $\mathrm{CO}_{2}$ extraction $\left(\mathrm{SC}-\mathrm{CO}_{2}\right)$ of Malbec grape seed oil (SUM) were performed at 200 and 400 bar, 40 and $60^{\circ} \mathrm{C}$ with a $\mathrm{CO}_{2}$ flow rate of $0.26 \mathrm{~kg} / \mathrm{h}$. The model of broken and intact cells developed by Sovová adequately described $\mathrm{SC}-\mathrm{CO}_{2}$ processes (AARD\% 0.88 1.064). It was demonstrated that the extraction of type $A$ was the most suited to apply. The solubility of $\mathrm{SUM}$ in $\mathrm{SC}-\mathrm{CO}_{2}$ was estimated and modeled by the Chrastil model (AARD\% 1.16 - 2.08). The highest value of the oil solubility was obtained at 400 bar and $60 \circ \mathrm{C}$. SUM extracted by $\mathrm{SC}-\mathrm{CO}_{2}$ was found high quality, and rich of linoleic and oleic acid.
\end{abstract}

Keywords: Grape Malbec seed oil, Supercritical $\mathrm{CO}_{2}$ extraction, Savova's model, Solubility.

\section{INTRODUCTION}

The malbec grape (Vitis vinífera) is the most important crop for the wine industry. Its use in Peru, in the elaboration of wine, pisco and derivatives, is represented by the viticultural industrial companies and mostly by artisanal wineries; As a consequence of the viticultural processing, by-products of great interest arise due to their high bi-active composition [1]. Among these by-products, the seed is found to have a high content of phenolic compounds, due to its high antioxidant activity; Cardio-protective benefits, antiviral, antibacterial and provide protection against UV rays [2]. In Peru and countries at the regional level, grapeseed oil is a little widespread product, its consumption is scarce and little is known about its nutritional value [3].

Supercritical fluid extraction (SFE) using carbon dioxide (SC$\mathrm{CO}_{2}$ ) is considered as green extraction technology, because it has mainly focused on the discovery and design of new extraction processes with reduced energy needs, using nonhazardous alternative solvents and renewable natural products, while ensuring safe and high quality extracts [4]. This technology provides attractive features overcoming many of the limitations of conventional extractions [5]. Therefore, taking into account the current framework, there is a growing interest in the use and application of SFE in the extraction of natural compounds from different arrays.

The mathematical modelling of experimental data by SFE extraction is important for the optimization of processes and to

Digital Object Identifier (DOI):

http://dx.doi.org/10.18687/LACCEI2020.1.1.93

ISBN: 978-958-52071-4-1 ISSN: 2414-6390 achieve a commercial success at scale up [6]. The broken and intact cell (BIC) model proposed by Sovová [7] was based on differential mass balance integration and has been successfully applied in the extraction of oils from different kinds of matrices [8]. Two adjustable parameters have been used and the mass transfer coefficients, both in the solid and fluid phase, were obtained by fitting of the experimental data. In this work, supercritical carbon dioxide $\left(\mathrm{SC}-\mathrm{CO}_{2}\right)$ extraction was performed in the extraction of vitis vinifera malbec seeds oil. The composition of the oil extracted was analyzed by gas chromatography-mass spectrometry (GC-MS). The BIC model, with two adjustment parameters, was then applied to describe the extraction process. Finally, the modeling results were applied to estimate the effects of pressure and temperature on the oil extraction.

The solubility of a solute in supercritical fluid is important to evaluate the feasibility and effectiveness of the process. However, experimental determination of solubility of solids in $\mathrm{SC}-\mathrm{CO}_{2}$ is not an easy or inexpensive task. Therefore, models able to correlate and predict solubility of solids in $\mathrm{SC}-\mathrm{CO}_{2}$ are very desirable [9]. To the best of our knowledge, there is no information in the available literature on evaluation of SUM solubility in $\mathrm{SC}-\mathrm{CO}_{2}$.

In view of this, the aim of the present work is to study the extraction kinetics of SUM at different pressure and temperature conditions by using the model of broken and intact cell (BIC) and to evaluate the solubility of malbec seeds oil in SC- $\mathrm{CO}_{2}$ by Chrastil model. The composition of SC- $\mathrm{CO}_{2}$ oil in terms of fatty acids will be presented.

\section{MATERIAL AND METHODS}

\section{Raw material and Chemical}

Vitis Vinifera Malbec seeds (SUM) was from industrial waste donated by the wine company (Santiago Queirolo) located in Lima-Peru). The initial moisture content of the collected malbec seeds was $78.7 \pm 0.5 \%(\mathrm{w} / \mathrm{w})$ and after drying at room temperature $7.10 \pm 0.3 \%$ (w/w) hence water should not affects the extraction as the value is lower than $20 \mathrm{wt} \%$ [10]. The Malbec seeds were grinded and sieved at a particle size distribution of $180-1000 \mu \mathrm{m}$. Before $\mathrm{SC}-\mathrm{CO}_{2}$ extraction, the grinded biomass was stored at $1{ }^{\circ} \mathrm{C}$ to avoid the chemical degradation of the lipids. $\mathrm{CO}_{2}$ was provided by Praxair (Peru)

18th LACCEI International Multi-Conference for Engineering, Education, and Technology: "Engineering, Integration, and Alliances for a Sustainable Development" "Hemispheric Cooperation for Competitiveness and Prosperity on a Knowledge-Based Economy", 27-31 July 2020, Virtual Edition. 
with a purity of $99.9 \%$, n-hexane $(99.8 \%$, Merck Millipore EEUU) was used to make the organic solvent extraction to determine the total oil content of the kernels.

\subsection{Extraction techniques}

\subsubsection{Soxhlet extraction}

About $15 \mathrm{~g}$ of ground malbec seeds were transferred into a filter paper extraction thimble and extracted with $200 \mathrm{~mL} \mathrm{n}$ hexane for $6 \mathrm{~h}$ at a maximum temperature of $70^{\circ} \mathrm{C}$ in a Soxhlet apparatus. After extraction was completed, n-hexane was removed at $50^{\circ} \mathrm{C}$ under reduce pressure using a rotary evaporator (Rotavapor Senco R5005KB). Subsequently, the flask was placed into a desiccator until a constant weight was attained. The extracted oil yield was expressed in percentage, which is defined as weight of oil extracted over weight of the sample taken.

\subsubsection{Supercritical fluid extraction}

The extraction unit used for this study is a laboratory scale extraction device supplied by Supercritical Fluid Technologies, Inc. (SFT-150, Newark - EEUU). The extraction reactor is a stainless-steel vessel of $100 \mathrm{ml}$ placed in a heater. This autoclave has at its ends two flat stainless-steel frit filters (pore diameter distribution of $10 \mu \mathrm{m}$ ). The operating and the details of the extraction device have already been described in other studies [11, 12].

For each experiment, the mass introduced in the extraction autoclave was comprised between 39 and 40g. Regarding the small charges used for $\mathrm{SC}-\mathrm{CO} 2$ extraction experiments, the efficiency of the extraction was estimated relative to the mass losses of the sample in the extraction autoclave:

$$
\mathrm{e}^{\prime}(\%)=\frac{\text { mass extracted }(\mathrm{kg})}{\text { mas introduced in the reactor }(\mathrm{kg})} \times 100
$$

SC- $\mathrm{CO}_{2}$ extraction experiments were conducted at pressures of 200 and $400 \mathrm{bar}$, temperatures of 40 and $60^{\circ} \mathrm{C}$, and a $\mathrm{CO}_{2}$ flowrate of $0.26 \mathrm{~kg} / \mathrm{h}$. The extraction curves were plotted as the variation of the mass losses of the sample as a function of the $\mathrm{CO}_{2} /$ biomass mass ratio. At the end of an extraction experiment, the extracted oil was collected in vials of $20 \mathrm{ml}$.

\subsection{Analytical methods}

\subsubsection{Fatty acid composition}

- Determination of the fatty acid profile. An Agilent Technologies 7890 Gas Chromatograph with Agilent Technologies 5975C mass spectrometer detector was used. Column: DB-5ms, $325^{\circ}$ C: $60 \mathrm{~m}$ x $250 \mu \mathrm{m}$ x $0.25 \mu \mathrm{m}$. Run time: 37.5 min. Injection: $5 \mu \mathrm{L}$. Split: 100: 1 . Carrier gas: He, $1 \mathrm{ml} / \mathrm{min}$. Sample: One hundred $\mathrm{mg}$ of ethereal extract was dissolved with $10 \mathrm{ml}$ of pentane and $100 \mu \mathrm{L}$ of $11.2 \% \mathrm{KOH}$ in methanol was added. It was stirred for 1 minute and centrifuged. The supernatant was injected directly into the GC-MS.

\subsection{Kinetic modelling}

The broken and intact cell model, proposed by Sovova et, al. [13-15], has been the most adopted approach in SFE modelling and is devoted to matrices submitted to milling in which two distinct structures are left to be extracted: cells with broken walls and intact cells [16]. The assumption is that the extraction kinetics from broken cell is faster than that from intact cells, since cell walls introduce an additional mass transfer resistance. Therefore, from the broken cell the mass transfer mechanism is convection, whereas through the intact inner core is molecular diffusion [17].In BIC model, it is also assumed that temperature and pressure are constant during the whole extraction time, particle size and solute distribution are uniform in the packed bed, the void fraction is constant during the extraction, and axial dispersion can be neglected.

According to the BIC model, the extraction comprises two stages: (i) Constant Extraction Rate (CER), which includes the extraction of solutes with greater ease of access. (ii) Falling Extraction Rate (FER), which includes the progressive decrease of the extraction rate and the diffusion of solutes from intact cells. For the application of the BIC model it is necessary to determine several preliminary parameters, such as, experimental extraction yield (e) and the relative amount of passed solvent (q).

$e=\frac{E}{N_{m}}$

$q=\frac{Q^{\prime} t}{N_{m}}$

$C_{u}=\frac{x_{u}}{1+x_{u}}$

Where $E$ is the amount of extract $(\mathrm{kg}), M$ is the mass of passed solvent $(\mathrm{kg}), Q^{\prime}$. Solvent flow rate $(\mathrm{kg} / \mathrm{h})$ and $t$ is the extraction time (h). The charge of insoluble solid, $N_{m}$ is calculated as:

$N_{m}=\left(1-C_{u}\right) N$

Where $N$ is the solid loaded in the extractor $(\mathrm{kg})$. The value of $C_{u}$ is the solute content in the untreated solid. Solute concentration in the untreated solid $x_{u}$ (with insoluble solid as reference).

According to the study published by Sovová [18], the supercritical fluid extraction curves can be divided in four types A, B, C or D by referring to the first part of extraction curves: if the first part of the extraction curve consists of one straight section, the type is $\mathrm{A}$ or $\mathrm{D}$. If it consists of two straight sections, it is of type B or C.
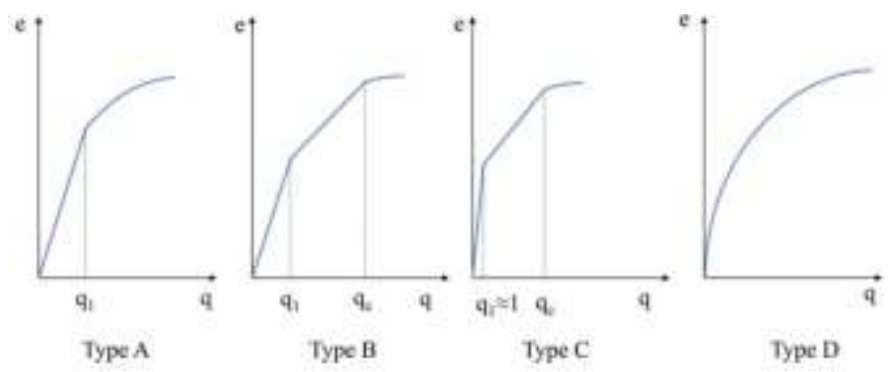

Fig.1. Shapes of the extraction curves for the different types of extraction reported in the Sovová's mathematical model.

The equations of BIC model to calculate the extraction yield $\left(\mathrm{kg}_{\text {oil }} / \mathrm{kg}_{\text {insolublebiomass }}\right)$ : 
CER stage: $e=q y_{s} \quad$ for $0 \leq q \leq q_{1}$

$q_{1}=\frac{r\left(x_{u}-x_{t}\right)-\gamma K x_{t}}{y_{s}-K x_{t}}$

$e=q_{1} y_{s}+\left(q-q_{1}\right) K x_{t} \quad$ for $q_{1} \leq q \leq q_{c}$

FER stage: $e=x_{u}\left[1-c_{1} \exp \left(-c_{2} q\right)\right]$ for $q>q_{c}$

A straight line of slope $y_{s}$, which represents the solubility of the extracted oil in $\mathrm{SC}-\mathrm{CO}_{2}$ is fitted to the first part of the extraction curve Eq.(5).The values of $\mathrm{q}_{c}$ and $\mathrm{q}_{1}$ were determined by taking into account the fact that:

- $\mathrm{q}_{\mathrm{c}}$ is the value of $\mathrm{q}$ at the crossing point with the estimate for the second part of the extraction curve according to Eq.(7) and

- $\mathrm{q}_{1}$ is the value of $\mathrm{q}$ at the crossing point with the first linear part Eq. (5) and the second straight part Eq. (7) considering the expression of q1 in Eq. (6).

The second part of the extraction curve $\left(\mathrm{q}>\mathrm{q}_{\mathrm{c}}\right)$ is described by Eq. (8) by adjusting constant parameters $\mathrm{C}_{1}$ and $\mathrm{C}_{2}$. Estimations of parameters $k_{s} a_{s}$, the mass transfer coefficient, and $r$, the fraction of the broken cell, can be obtained by considering Eq. (9) to 10:

$r=1-c_{1} \exp \left(-c_{2} q_{c}\right)$

$k_{s} a_{s}=\frac{(1-r)(1-\varepsilon) Q^{\prime} C_{2}}{N_{m}\left[1-\left((1-r) \frac{C_{2}}{K}\right)\right.} \quad$ para $x_{t}>0$

Where $\varepsilon$ is the bed porosity, $\mathrm{Q}^{\prime}$ is the solvent flow rate $(\mathrm{kg} / \mathrm{h})$ and $\mathrm{N}_{\mathrm{m}}$ is the charge of insoluble solid $(\mathrm{kg})$.

\subsection{Solubility modelling}

The experimental solubility $\left(\mathrm{y}_{\mathrm{s}}\right)$ data were calculated from the initial slope of the first period of extraction curve Eq.(5), and modelled using the Chrastil's [19] equation:

$\ln \left(y_{s}\right)=k \ln \rho_{c o 2}+\frac{a}{T}+b$

Where $y_{\mathrm{s}}$ is the solubility of the solute in the supercritical fluid, $\mathrm{k}$ is the slope of the linear correlation and represents the average number of solvent molecules in solvated complex, $a$ is function of the heat of solvation and vaporization of solute and $b$ is another constant that depends on the molecular weight and melting point of the solute and the fluid.

\subsection{Statistical analysis}

The adjustable parameters $C_{1}$ and $C_{2}$ were calculated by minimizing the sum of least squares between the experimental and calculated values of e. The absolute average relative deviation (AARD) given in Eq. (11), was used to evaluate the efficiency of the model.

$$
A A R D(\%)=\frac{100}{n} \sum\left[\frac{\text { Rend. exp.-Rend. calc. }}{\text { Rend.exp. }}\right]
$$

Where $\mathrm{n}$ is the number of experimental points composing a kinetic curve. Rend. Exp, is an experimental yield and rend. Calc, is a calculated yield.

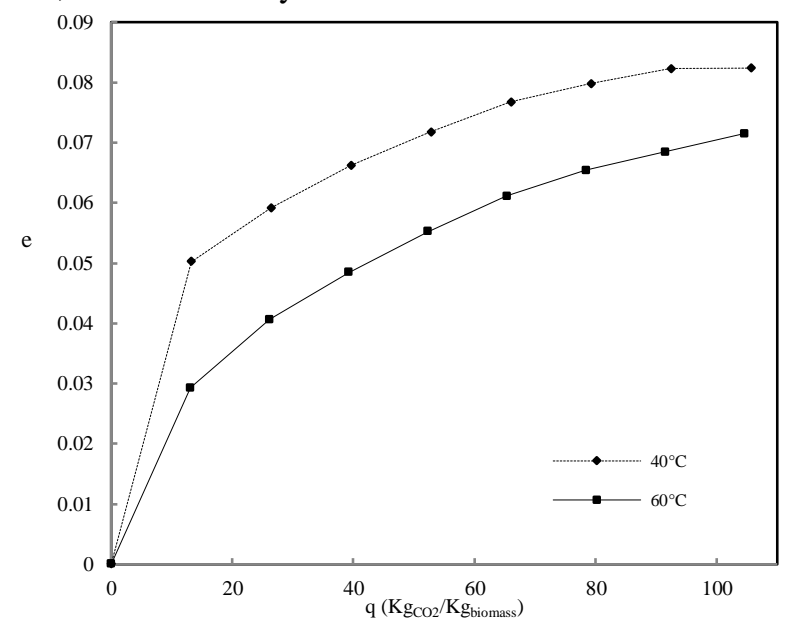

(a)

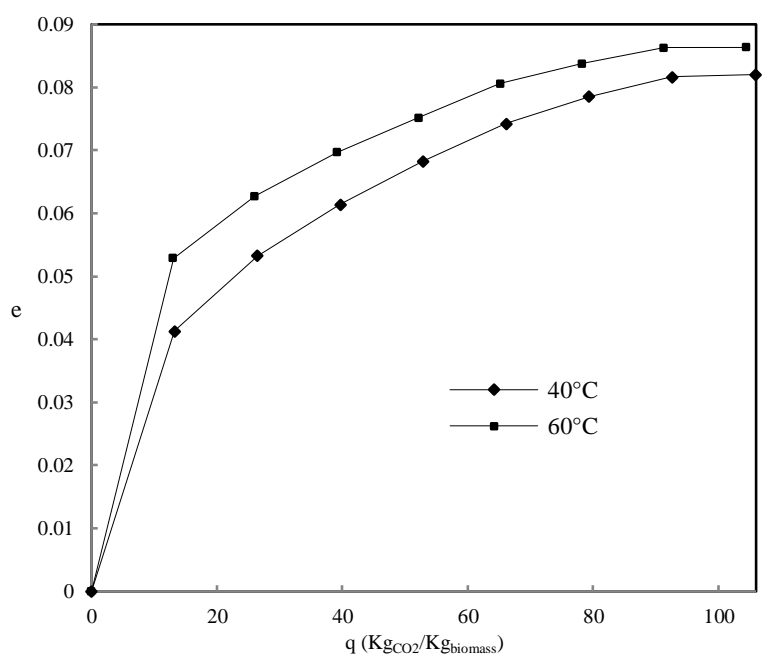

(b)

Fig. 2 Experimental and modelled SUM SC- $-\mathrm{CO}_{2}$ extraction curves: Effects of temperature at (a) 200 bar and (b) 400 bar.

\section{RESULTS AND DISCUSSION}

3.1 Effects the temperature and pressure

The experimental and modelled kinetic curves obtained by plotting "e" ( $\mathrm{kg}$ oil $/ \mathrm{kg}$ insoluble biomass) versus "q" $\left(\mathrm{kgCO}_{2} / \mathrm{kg}\right.$ biomass ratio) with mean value \pm 0.03 standard error $(\mathrm{n}=3)$ are presented in Fig. 2. Temperature effects on the extraction yield were studied at 40 and $60^{\circ} \mathrm{C}$ at fixed pressure of 200 and 400 bar (Fig. 2a-b). The experimental kinetic curves showed common shapes, where it can be noticed that the mass transfer rate was not constant. As usually reported for the typical kinetic curves observed for the extraction of natural products [20], these extraction curves

18th LACCEI International Multi-Conference for Engineering, Education, and Technology: "Engineering, Integration, and Alliances for a Sustainable Development" "Hemispheric Cooperation for Competitiveness and Prosperity on a Knowledge-Based Economy", 29-31 July 2020, Buenos Aires, Argentina. 
seem to consist of two distinct phases: constant extraction rate period (CER), falling extraction rate period (FER).

The extraction curves are presented in Fig. 2. It can be seen that for all experiments, when it was possible to perform extraction until its end, the maximal mass loss reached is about $8.63 \%$. This value is very close to the value obtained by n-hexane extraction $(9.14 \%)$.

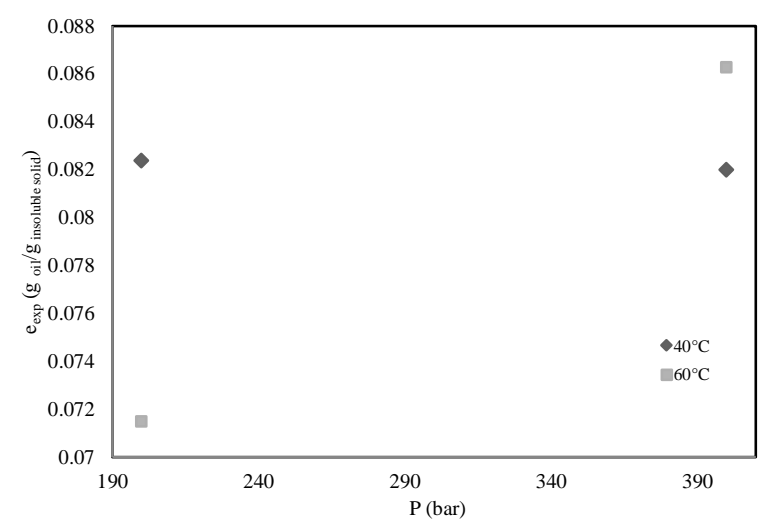

(a)

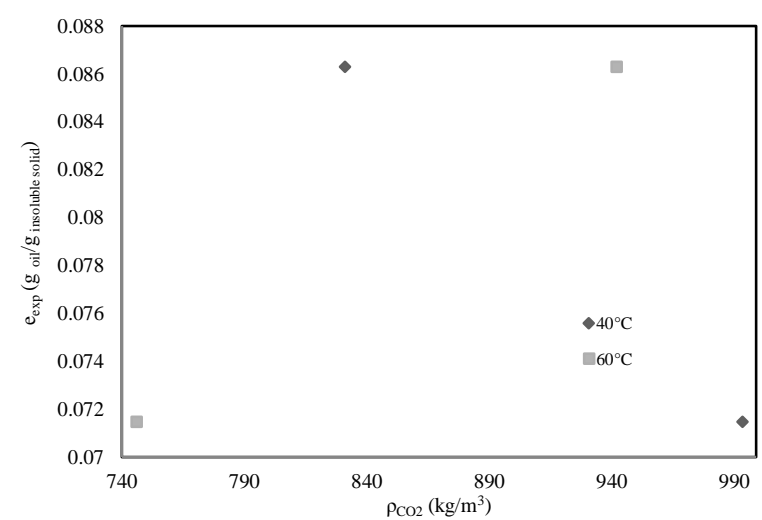

(b)

Fig. 3. Experimental yield of supercritical $\mathrm{CO}_{2}$ extraction at $40^{\circ} \mathrm{C}$ and $60^{\circ} \mathrm{C}$ as a function of (a) pressure and (b) solvent density
As shown in Fig. 2 (a), it can be observed that at 200 bar, the extraction yield decreases from 0.0824 to $0.0715 \mathrm{~g}$ oil $/ \mathrm{g}$ insoluble solid with increasing temperature from 40 to $60^{\circ} \mathrm{C}$. An increase in temperature results in a decrease in $\mathrm{SC}-\mathrm{CO}_{2}$ density, which in turn lowers its solvating power, decreasing the extraction yield (e). At 400 bar (Fig. 2(b)) an increase of temperature from 40 to $60^{\circ} \mathrm{C}$ leads to an increase of e from 0.08 to $0.085 \mathrm{~g}$ ${ }_{\text {oil }} / \mathrm{g}$ insoluble solid. This is due to the solute vapor pressure, that increases with temperature.

In Fig. 3 the experimental yields of $\mathrm{SC}-\mathrm{CO}_{2}$ extraction at 40 and $60{ }^{\circ} \mathrm{C}$ as a function of (a) pressure and (b) solvent density with mean value \pm 0.02 standard error $(\mathrm{n}=3)$ are reported. Both at $40{ }^{\circ} \mathrm{C}$ with increasing pressure at 200 and 400 bar, the extraction yield has a non-significant decrease from 0.0824 to $0.0820 \mathrm{~g} \mathrm{oil} / \mathrm{g}$ insoluble solid, despite the increase of $\mathrm{SC}-\mathrm{CO}_{2}$ density and its dissolving power. This could be due to the decrease in the diffusivity of the oil in $\mathrm{SC}-\mathrm{CO}_{2}$ at high pressures [21, 22]. Moreover, as suggested by FariasCampomanes et al. [23], the low mass-transfer rates at high pressure may be partially due to the low dispersion coefficient of the $\mathrm{SC}-\mathrm{CO}_{2}$ which accounts for the axial dispersion and radial diffusion mechanisms, and the high porosity of the extraction bed. Instead, at $60{ }^{\circ} \mathrm{C}$ the increasing of pressure leads to increase the extraction yield from $0.0715 \mathrm{~g}$ oil $/ \mathrm{g}$ insoluble solid to $0.0863 \mathrm{~g}$ oil $/ \mathrm{g}$ insoluble solid. This indicates that the solute vapor pressure plays a dominating role on $\mathrm{CO}_{2}$ density. The best extraction yield of $0.0863 \mathrm{~g}$ oil $/ \mathrm{g}$ insoluble solid was obtained at $400 \mathrm{bar}, 60{ }^{\circ} \mathrm{C}$ and $0.26 \mathrm{~kg} / \mathrm{h} \mathrm{CO}$ flow rate. According to Cao and Ito [24], high pressures significantly increase the oil extraction yield and the amount of unsaturated fatty acids present in the grape seed; while the temperature has no significant influence. With respect to the $\mathrm{CO}_{2}$ flow rate, the values used are similar to those reported by Farias Camponaes [23] that worked with $0.31 \mathrm{Kg} / \mathrm{h} \mathrm{CO}$ flow rate.

$\underline{\text { Table 1. BIC model parameters evaluated from experimental data of Malbec seed oil extraction by } \mathrm{SC}-\mathrm{CO}_{2}}$

\begin{tabular}{cccccccc}
\hline $\mathrm{P}$ & $\mathrm{T}$ & $\rho_{\mathrm{CO} 2}$ & $\mathrm{R}$ & $\mathrm{k}_{\mathrm{s}} \mathrm{a}_{\mathrm{s}} 10^{-4} 1$ & $\mathrm{y}_{\mathrm{s}} 10^{-3} 1$ & $\mathrm{q}_{\mathrm{c}}{ }^{1}$ & AARD \\
\hline (bar) & $\left({ }^{\circ} \mathrm{C}\right)$ & $\left(\mathrm{kg} / \mathrm{m}^{3}\right)$ & - & $\left(\mathrm{m}^{-1} \mathrm{~s}^{-1}\right)$ & $\left(\mathrm{Kg}_{\text {oil }} / \mathrm{kg}_{\mathrm{CO} 2}\right)$ & $\left(\mathrm{kg}_{\mathrm{CO} 2} / \mathrm{Kg}_{\text {biomass }}\right)$ & $(\%)$ \\
200 & 40 & 831,265 & 0,05569 & $1,62 \pm 0.02$ & $0,78 \pm 0.02$ & $43,912 \pm 0.01$ & $1,014 \%$ \\
200 & 60 & 746,333 & 0,03247 & $2,03 \pm 0.01$ & $0,68 \pm 0.01$ & $43,468 \pm 0.02$ & $0,880 \%$ \\
400 & 40 & 993,599 & 0,04584 & $2,51 \pm 0.02$ & $0,77 \pm 0.02$ & $29,355 \pm 0.02$ & $1,010 \%$ \\
400 & 60 & 942,246 & 0,05869 & $2,01 \pm 0.01$ & $0,82 \pm 0.01$ & $28,950 \pm 0.03$ & $1,064 \%$
\end{tabular}

${ }^{1}$ Mean value \pm standard error $(n=2)$ 


\subsection{Kinetic modelling}

In Fig. 2 shows that the BIC model was able to fit accurately the experimental extraction curves. In Table 1 the values of the BIC model parameters fitted on the experimental data of SUM's oil are reported.

The average absolute relative deviation (AARD) values, ranging between 0.880 and $1.064 \%$, for the modelling performed on the experimental data, confirm the good quality of the BIC model to describe the extraction curves of SUM's oil. The increase of pressure from 200 to $400 \mathrm{bar}$ at constant temperature of 40 and $60^{\circ} \mathrm{C}$ led to an increase of grinding efficiency (r), from 0.324 to 0.587 , so the extraction yield increased from 0.0715 to $0.0863 \mathrm{~g}_{\text {oil }} / \mathrm{g}_{\text {insoluble solid, }}$ this could indicate the damage/destruction of the oil cells structure under high pressure. Similar results were reported for pomegranate seed oil by [25].

The solubility in supercritical fluid is probably the most important thermo-physical property since it determines how much solute can be dissolved into the solvent. The solubility $\left(\mathrm{y}_{\mathrm{s}}\right)$ of SUM decreased at 200 and 400bar with increasing temperature from 40 to $60^{\circ} \mathrm{C}$ as result of $\mathrm{SC}-\mathrm{CO}_{2}$ density decrease. The highest value of the oil solubility 0,826 $\mathrm{g}_{\text {oii }} / \mathrm{kg}_{\mathrm{CO} 2}$ was obtained at $400 \mathrm{bar}$ and $60^{\circ} \mathrm{C}$. This solubility value was of a similar magnitude to that of vitis vinifera seed oil by [27].

\subsection{Application of Chrastil's model to malbec seed oil}

Table 2 shows reports the calculated parameters for the solubility model of Chrastil's model a, b and k, at two different temperatures. The average absolute relative deviation (AARD) was found to be in the range 1.16-2.085\%, thus to indicate the Chrastil's equation fitting well with the solubility values $\left(\mathrm{y}_{\mathrm{s}}\right)$ obtained by modelling the extraction curves (Table $1)$.

Table 2. Solubility parameters of Chrastil's model for Malbec

\begin{tabular}{ccc}
\multicolumn{3}{c}{ seed oil } \\
\cline { 2 - 3 } Parameters & \multicolumn{2}{c}{ Temperature } \\
\cline { 2 - 3 }$k$ & $40^{\circ} \mathrm{C}$ & $60^{\circ} \mathrm{C}$ \\
$a$ & 2.02 & 9.61 \\
$b$ & -0.18 & -0.22 \\
\multirow{2}{*}{ AARD $(\%)$} & -21.46 & -72.56 \\
\hline
\end{tabular}

Fig. 4 shows the plots of $\ln \left(\mathrm{y}_{\mathrm{s}}\right)$ versus $\ln \left(\mathrm{CO}_{2}\right)$ using the Chrastil model in the pressure range of 200-400bar, temperature of 40 and $60^{\circ} \mathrm{C}$ and at a constant $\mathrm{CO}_{2}$ flow rate of $0.26 \mathrm{~kg} / \mathrm{h}$. The straight lines representing the calculated values are in good agreement with the experimental data and different slopes of the solubility isotherms can be observed. The solubility increases with the $\mathrm{CO}_{2}$ density at $60{ }^{\circ} \mathrm{C}$, while the solubility decreases at $40^{\circ} \mathrm{C}$ with respect to the $\mathrm{CO}_{2}$ density. Since as the temperature decreases, the $\mathrm{CO}_{2}$ density decreases, as does its solvation power, the higher solubility valued at 60 ${ }^{\circ} \mathrm{C}$ can be attributed to the predominant effect of the vapor pressure of solute on the $\mathrm{CO}_{2}$ density.

Fig. 5 shows the adjustment results of the experimental solubility data to the Chrastil model plotted against pressure. However, Fig. 6 confirms the crossing point close to 240bar. Below the crossover value, the solubility decreases with increasing temperature from 40 to $60^{\circ} \mathrm{C}$ because the $\mathrm{CO}_{2}$ density prevails over the vapor pressure of the solute. Instead, above the crossover value, solubility increases with temperatures, as the vapor pressure of the solute becomes the dominant factor. The highest solubility was evaluated at 400 bar and $60^{\circ} \mathrm{C}$, while the lowest at 200 bar and $60^{\circ} \mathrm{C}$.

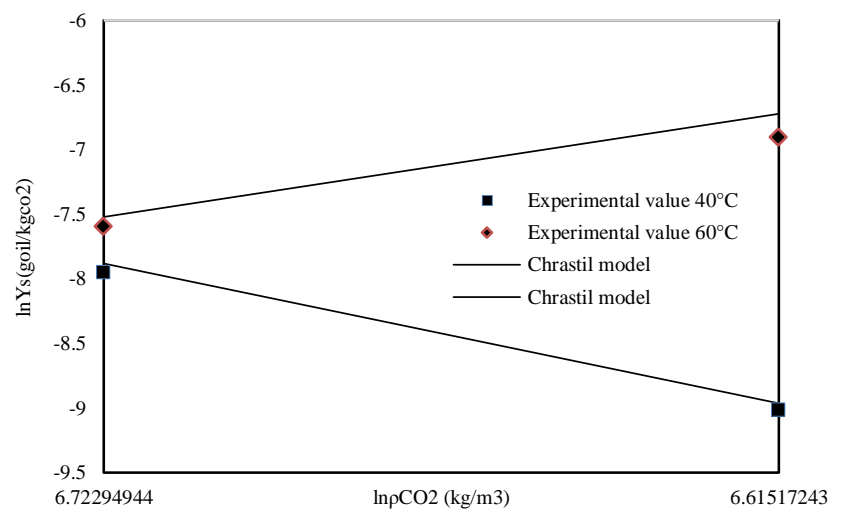

Fig. 4. Fitting results of the experimental solubility data to the chrastil model plotted versus $\ln \rho_{\mathrm{CO} 2}$

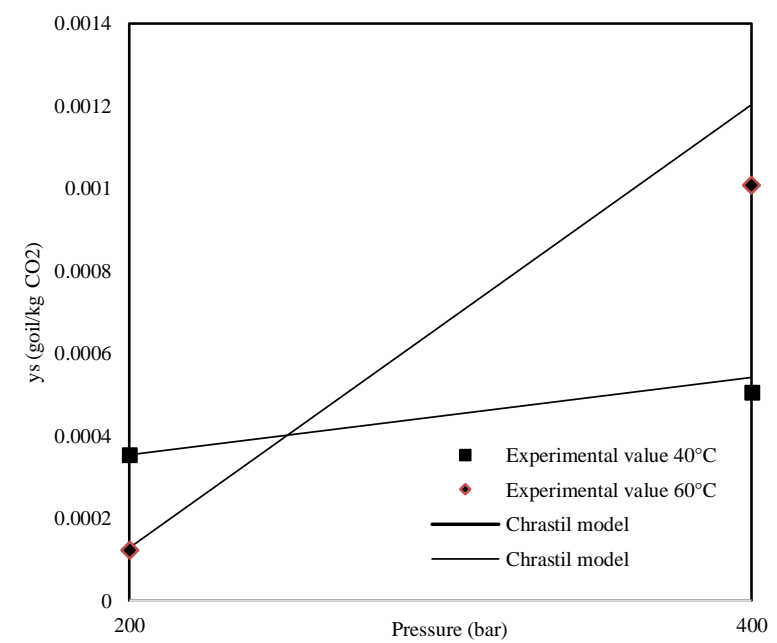

Fig. 5. Fitting results of the experimental solubility data to the chrastil model plotted versus pressure 
3.4 Malbec seed oil composition obtained by $\mathrm{SC}-\mathrm{CO}_{2}$

Table 3. Percentage ratio of fatty acids present in the supercritical oil obtained

\begin{tabular}{lc}
\hline Fatty Acids & $\begin{array}{c}\text { Relative } \\
\text { Concentration }(\%)^{1}\end{array}$ \\
\hline Saturated & $12,9 \pm 0.02$ \\
Monounsaturated & $22,2 \pm 0.01$ \\
Polyunsaturated & $64,9 \pm 0.03$ \\
\hline Mean value \pm standard error $(\mathrm{n}=2)$
\end{tabular}

Table 3 reports the percentage ratio of fatty acids present in the supercritical oil obtained, where it was obtained that saturated fatty acids represent 12.32 percent, the result of which is close to that reported by [28]. With respect to monounsaturated fatty acids, they were 22.2 percent, being higher than reported by [28] of 18.12 percent because the research was carried out on the oil of the black grape seed. In the case of polyunsaturated fatty acids, they turned out to be the components with the highest proportion represented by 64.9 percent, however, the result was close to what was reported by [29] of 65.34 percent referred to the seed oil of Syrah grape.

Table 4. Content of fatty acids (\% of total fatty acids) in the supercritical oil obtained

\begin{tabular}{lc}
\hline Fatty Acids & $\begin{array}{c}\text { Relative Concentration } \\
(\%)^{1}\end{array}$ \\
\hline Mirístic (14:0) & $0,1 \pm 0.01$ \\
Palmitoleic (16:1) & $0,2 \pm 0.01$ \\
Palmitic (C16:0) & $7,5 \pm 0.02$ \\
Linoleic (18:2) & $64,9 \pm 0.04$ \\
Oleic (18:1) & $21,8 \pm 0.0$ \\
Esteáric (C18:0) & $5,2 \pm 0.01$ \\
Cis-eicosenoic (C20:1) & $0,2 \pm 0.01$ \\
Eicosane (C20:0) & $0,1 \pm 0.01$ \\
\hline${ }^{1}$ Mean value \pm standard error $(\mathrm{n}=2)$
\end{tabular}

Table 4 reports the types of fatty acids present in the supercritical oil obtained and their relative concentration. Linoleic acid and oleic acid with 64.9 percent and 21.8 percent respectively; which was very close to what was reported by [30] regarding oleic acid and linoleic acid, with 22 percent and 67 percent respectively. The results of [28] were for oleic acid of 17.36 by the way and linoleic acid of 68.75 by the way, whose values were close to those obtained in the present investigation.

\section{CONCLUSIONS}

In the present investigation, the use of the broken and intact cell model developed by Sovová resulted in describing the SC$\mathrm{CO}_{2}$ processes for the extraction of malbec grape seed oil. It was established that type A extraction was the most appropriate to apply since the experimental extraction curves are divided into two parts. The $\mathrm{SC}-\mathrm{CO}_{2}$ extraction processes of SUM were mainly governed by the external resistance of mass transfer (e). Using the Chrastil density-based model, it was found that SUM solubility data correlated well with the model within the range of experimental conditions. SUM oil extracted by $\mathrm{SC}-\mathrm{CO}_{2}$ has a superior quality and is rich in linoleic and oleic acid.

\section{ACKNOWLEDGMENT}

The authors thank the ITEPA-PUCP Research Group and the Industrial Process Laboratory - Industrial Engineering Section PUCP - PERÚ.

\section{REFERENCES}

[1] Obregon, H. 2019. Propuesta de diseño de un aceite de semilla de uva proveniente de los residuos de la industria vitivinícola basado en la metodología Design For Six Sigma. Tesis para optar el grado de magister en Ingeniería Industrial con mención en gestión de operaciones. Escuela de Posgrado - Pontificia Universidad Católica del Perú. Lima Perú.

[2] Molero, A.; Pereyra, C.; Martinez, E. 1996. The Chemical Engineering Journal and the Biochemical Engineering Journal. Recovery of grape seed oil by liquid and supercritical carbón dioxide extraction: a comparison with conventional solvent extraction. 1996, 227-231. doi.org/10.1016/0923-0467 (95)03040-9

[3] Obregon, H; Huayta, F; Cardenas, F. 2018. Optimización del Proceso de Extracción por Fluidos Supercríticos en la Obtención de Aceite de Semillas de Uva con el Empleo de la Metodología Taguchi y Superficie de Respuesta. 16th LACCEI International Multi-Conference for Engineering, Education, and Technology: "Innovation in Education and Inclusion". Lima - Peru.

[4] Chemat, F.; Vian, M.; Cravotto, G. 2012. Green extraction of natural products: concept and principles, Int. J. Mol. Sci. 13 (2012) 8615-8627.

[5] Lindy, J. 2014. Supercritical Fluid Extraction (Technology, Applications and Limitations), Nova Science Publishers, Inc., New York, 2014.

[6] M.M.R. De Melo, A.J.D. Silvestre, C.M. Silva, Supercritical fluid extraction of vegetable matrices: applications, trends and future perspectives of a convincing green technology, J. Supercrit. Fluids 92 (2014) 115-176, http://dx.doi.org/10.1016/j.supflu.2014.04.007

[7] H. Sovová, Rate of the vegetable oil extraction with supercritical CO2. I. Modelling of extraction curves, Chemical Engineering Science 49 (1994) $409-412$

[8] J. Stastova, J. Jez, M. Bartlova, H. Sovová, Rate of the vegetable oil extraction with supercritical CO2-III. Extraction from sea buckthorn, Chemical Engineering Science 51 (1996) 4347-4352.

[9] T.J. Bruno, J.F. Ely, Supercritical fluid technology: reviews in modem theoryand applications, in: Supercrit. Fluid Technol. Rev. Mod. Theory Appl., CRCPress, Boca Raton, 2017, http://dx.doi.org/10.1201/9780203710180.

[10] A. Mouahid, C. Crampon, S.-A.A. Toudji, E. Badens, Effects of high water content and drying pre-treatment on supercritical $\mathrm{CO} 2$ extraction from 
Dunaliella salina microalgae: experiments and modelling, J. Supercrit. Fluids 116 (2016) 271-280, http://dx.doi.org/10.1016/j.supflu.2016.06.007.

[11] Navas, P. 2010. Caracterización físico-química del aceite de semilla de uva extraído con solvente en frio. Revista de la Facultad de Agronomía (LUZ). 2010,27:270-288.

[12] Molero, A.; Pereyra, C.; Martinez, E. 1996. The Chemical Engineering Journal and the Biochemical Engineering Journal. Recovery of grape seed oil by liquid and supercritical carbón dioxide extraction: a comparison with conventional solvent extraction. 1996, 227-231. doi.org/10.1016/0923-0467 (95)03040-9

[13] H. Sovová, Broken-and-intact cell model for supercritical fluid extraction: its origin and limits, J. Supercritical. Fluids 129 (2017) 3-8, http://dx.doi.org/10.1016/j.supflu.2017.02.014.

[14] H. Sovová, Rate of the vegetable oil extraction with supercritical CO2I.Modelling of extraction curves, Chem. Eng. Sci. 49 (1994) 409-414, http://dx.doi.org/10.1016/0009-2509(94)87012-8.[29]

[15] H. Sovová, J. Ku`cera, J. Je`z, Rate of the vegetable oil extraction with supercritical CO2-II. Extraction of grape oil, Chem. Eng. Sci. 49 (1994)415-420, http://dx.doi.org/10.1016/0009-2509(94)87013-6.

[16] M.M.R. De Melo, A.J.D. Silvestre, C.M. Silva, Supercritical fluid extraction ofvegetable matrices: applications, trends and future perspectives of aconvincing green technology, J. Supercrit. Fluids 92 (2014) 115-176, http://dx.doi.org/10.1016/j.supflu.2014.04.007.

[17] E.L.G. Oliveira, A.J.D. Silvestre, C.M. Silva, Review of kinetic models for supercritical fluid extraction, Chem. Eng. Res. Des. 89 (2010) 11041117, http://dx.doi.org/10.1016/j.cherd.2010.10.025.

[18] H. Sovová, Mathematical model for supercritical fluid extraction of natural products and extraction curve evaluation, J. Supercrit. Fluids 33 (2005) 35-52, http://dx.doi.org/10.1016/j.supflu.2004.03.005.

[19] J. Chrastil, Solubility of solids in supercritical gases, J. Chem. Phys. 86 (1982)3016-3021, http://dx.doi.org/10.1063/1.443931.

[20] T.J. Bruno, J.F. Ely, Supercritical fluid technology: reviews in modem theoryand applications, in: Supercrit. Fluid Technol. Rev. Mod. Theory Appl., CRCPress, Boca Raton, 2017, http://dx.doi.org/10.1201/9780203710180

[21] K.K. Liong, N.R. Foster, S.S.T. Ting, Solubility of fatty acid esters in supercriticalcarbon dioxide, Ind. Eng. Chem. Res. 31 (1992) 400-404, http://dx.doi.org/10.1021/ie00001a054.

[22] K.A. Rezaei, F. Temelli, Using supercritical fluid chromatography to determinediffusion coefficients of lipids in supercritical $\mathrm{CO} 2, \mathrm{~J}$. Supercrit. Fluids 17(2000) 35-44, http://dx.doi.org/10.1016/S08968446(99)00039-X.

[23] A.M. Farías-Campomanes, M.A. Rostagno, M.A.A. Meireles, Production ofpolyphenol extracts from grape bagasse using supercritical fluids: yield,extract composition and economic evaluation, J. Supercrit. Fluids 77 (2013)70-78, http://dx.doi.org/10.1016/j.supflu.2013.02.006.

[24] X. Cao and Y. Ito, "Supercritical fluid extraction of grape seed oil and subsequent separation of free fatty acids by high-speed counter-current chromatography," Journal of Chromatography A, vol. 1021, no. 1-2, pp. 117-124, 2003.

[25] A. Natolina , C. Da Porto, Supercritical carbon dioxide extraction of pomegranate (Punicagranatum L.) seed oil: Kinetic modelling and solubility evaluation. J. of Supercritical Fluids 151 (2019) 30-39. https://doi.org/10.1016/j.supflu.2019.05.002

[26] A. Mouahid, H. Bouanga, C. Crampon, E.Badens. Supercritical CO2 extraction of oil from Jatropha curcas: An experimental and modelling study (20017). https://doi.org/10.1016/j.supflu.2017.11.014

[27] H. Sovova, M. Zarevucka, M. Vacek, K. Stransky. Solubility of two vegetable oils in supercritical CO2. The Journal of Supercritical Fluids Vol. 20, Issue 1 (2001), Pages 15-28. https://doi.org/10.1016/S0896$\underline{8446(01) 00057-2}$

[28] Córdova, G.; Núñez, A. 2015. Determinación del perfil de ácidos grasos de un aceite extraído de la semilla de vitis vinífera (Uva negra criolla). Repositorio Dspace. Recuperado el 26/03/18, de: http://repositorio.unprg.edu.pe/handle/UNPRG/139.
[29] Navas, P. 2009. Composición química del aceite virgen obtenido por extracción mecánica de algunas variedades de uva (Vitis vinífera L.) con énfasis en los componentes minoritarios. Archivos Latinoamericanos de Nutrición V.59 N². Facultad de Agronomía - Universidad Central de Venezuela. Maracay - Venezuela.

[30] Padley, F; Gunstone, F; Harwood, J. 1994. Occurrence and Characteristics of oils and fats. In: The Lipid Handbook. 2 ed. Chapman \& Hall, London p.88-113. 